\title{
(New) Bulgarian Enlighteners and Ambassadors? The Reinvention of National Identity in Times of Crisis
}

\begin{abstract}
Drawing on empirical data from 37 Bulgarian students and young professionals in the UK, this paper explores the intersection of the discourses produced by the European crises and migrants' national identity. In Bulgaria, the crisis narrative is embedded in the arguably never-ending democratic transition, manifested in socio-economic instability and political volatility. Simultaneously, "Brexit Britain" is enveloped in strong Eurosceptic sentiments, propelled by a combination of austerity measures and intensified Eastern European migratory flows. Both contexts subject Bulgarian migrants to stigmatizing representations. Looking at migrants' everyday practices, the data reveals that young Bulgarians draw on the related ideas of the "new" Enlightener and Ambassador to counterbalance negative discourses. Thus, the paper explores the meanings and significance attributed to the Enlighteners and the Ambassadors, arguing that the participants engage in "social creativity" and "individual mobility" strategies that lead to reinvention of national identity.
\end{abstract}

\section{INTRODUCTION}

The term "crisis" has become a "buzzword" in European public debates, applied to a wide range of political, social and economic phenomena: among many, the 2008 financial crash, the unprecedented scale of Syrian refugees in Europe, and Brexit. The consequences of these events are never simple and one-sided; therefore, the focus of discussion should be on the ongoing crises that can be observed in Europe today (Sierp and Karner, 2019), and on how the grand narratives on supranational and national level intersect, affecting the personal and intimate. To contribute further to the better understanding of these processes and policy concerns regarding migration, this paper focuses on post-accession Bulgarian youth mobility to the UK. As such, this case-study offers a unique insight into how a group of relatively new and relatively less researched (compared at least to Poles and Romanians in Britain) EU citizens respond to the European crises and the othering discourses they produce in Bulgaria and Britain.

Specifically, the paper adopts a transnational lens to explore the intersection between the European crises and Bulgarian migrants' national identity. This approach understands "[t]ransnational migration [a]s the process by which immigrants forge and sustain simultaneous 
multi-stranded social relations that link together their societies of origin and settlement" (Glick Schiller et al., 1995: 48). Thus, transnationalism analyses the ways in which migrants manage the opportunities and challenges produced concurrently by host and home societies. A transnational perspective recognizes that state actors continue to shape but not limit the various cultural, political and socio-economic linkages that people forge across borders (Levitt and Glick Schiller, 2004). This in turn allows the exploration of how the European crises intersect on supranational and national level, affecting individuals' perception of self.

Consequently, by looking at migrants' everyday practices, this paper argues that university students and young professionals manage othering discourses by drawing on the romanticized idea of the $18^{\text {th }}$ century Bulgarian "Enlightener" and the related notion of an "Ambassador". The Enlightener is an umbrella term that refers to those who studied abroad while Bulgaria was under Ottoman rule and returned to contribute to the revival of the nation (Daskalov, 2004). Similarly, the participants in this study interpret their migratory choices by framing them within (new) Enlightener and Ambassadorial practices. While both terms are inductively conceptualized, their nature differs slightly. The Enlightener is a term of self-identification that participants refer to explicitly or implicitly when confronted with home-society stereotypical representations. In comparison, the Ambassador is an etic term employed by the author to describe participants' discursive defence against accusations of stigmatizing labels provided in the host society. Thus, this paper argues that by drawing on the (new) Enlightener and Ambassador, the participants engage in "social creativity" and "individual mobility" strategies (Tajfel and Turner, 1986), which not only counterbalance othering but also reclaim and reinvent their national identity in the process.

The article begins by contextually situating the study, which is followed by a consideration of its theoretical and methodological framework. Next, I present two empirical sections. The first considers how young Bulgarians manage home-society stereotypes in their everyday through the idea of the "new" Enlightener, and the second focuses on its counterpart, the Ambassador, which addresses host-society othering. Some of the criticisms associated with the (new) Enlightener and Ambassador are also considered. Finally, the conclusion summarizes the findings, highlighting policy implications for both Bulgaria and the UK. 


\section{CONTEXTUAL OVERVIEW}

Contextualising Bulgarian migration in Britain is crucial to understanding how governmental policies and public discourse have shaped the phenomenon. Therefore, this section, scrutinizes the perception of crisis in relation to migration in both Bulgaria and the UK. In Bulgaria, the contested nature of migration is predominantly explored with reference to the tension created between "leavers" (migrants) and "stayers" (non-migrants) whilst also considering alternative discourses. In Britain, the line of division is forged between the local population and migrants, resulting in an increasingly more restrictive immigration policy. In both cases however, nationalist discourses affect migrants' everyday.

In Bulgaria, a popular anecdote captures well the intersection between the crisis narrative and migration: "Question: What are the solutions to the crisis in Bulgaria? Answer: Terminal 1 and Terminal 2 of Sofia Airport" (Bozhidarov, 2012). This statement positions the state of crisis as a central characteristic of the socio-political and economic situation in Bulgaria, outlining migration as a coping strategy. Symbolically, Terminals 1 and 2 of Sofia Airport serve to delineate the divide between "leavers" (migrants) and "stayers" (non-migrants). This division contains manifold, emotionally charged connotations, which depict migration as a form of escapism at best, or as national betrayal at worst. Thus, the "stayers versus leavers" debate can be traced to communist policy approaches, which gave affective connotations equating it to treason as it was largely controlled, even punished by the authorities (Krasteva, 2014). Although less restricted in the 1990s, migration was also associated with disillusion over the course of transition to democracy. Economically, the transition crisis manifested itself in the 1990-91 coupon system implemented to address heat, power and food shortages in the country. In the early 1990s, Bulgarian industries crashed, unemployment rates increased, and hyperinflation eventually led to the collapse of the banking sector in 1996-97. These events were supplemented by political volatility and strong party polarization. The transition to democracy had social implications as well, arguably dividing the population into "winners" and "losers" depending on whether they have benefitted from the process (Kalinova and Baeva, 2011). This resulted in emigration, which was politically framed as escapism (Krasteva, 2014: 377), signifying the precedence of push over pull factors in migratory decisions. 
Bulgaria's EU accession in 2007 transformed the nature of migratory outflows, characterized as "drama-free and open-ended" (my translation; Krasteva, 2014: 377). Yet, the crisis narrative, underpinned by an arguably never-ending process of transition, not only retains its salience but also continues to shape attitudes towards migrants. The division between "stayers" and "leavers" resurfaced amidst anti-governmental protests in 2013, questioning the national loyalty of migrants Furthermore, this reveals the complex intersection of the crisis narrative on a supranational and national level where both push (the after-effects of the European crises) and pull factors (freedom of movement) operate simultaneously; yet, it is the push factors, once again, that emerge as key in shaping migratory decisions. This dominant narrative is often confronted by the policies of successive Bulgarian governments of different political leanings that have recognised emigration as an asset to the country, focusing on efforts to encourage return, particularly of the highly skilled (see Krasteva, 2014). Furthermore, frequent media coverage of those who have not only returned but also successfully launched careers in Bulgaria emphasises patriotism as one of the key reasons for doing so alongside a desire to build bridges between "stayers" and "leavers" (BNT, 2016), thus directly aiming to mitigate the discursive tension between migrants and nonmigrants.

Similarly, migration and intra-European mobility dominate British public discourse. Notably, Bulgarians (and Romanians) attracted attention shortly before and after the removal of labour restrictions on 1 January 2014, which was marked by a predominantly negative discourse. Such othering practices were further exacerbated during the EU referendum campaign. Contextually, the crisis narrative in Britain has become saturated with anxieties about the inability to cope with larger globalization processes and local regionalization movements that erode the power structures of the nation-state. This has led to a resurgence of a defensive national identity focused on a narrative about regaining sovereignty and control over Britain's borders. Therefore, Brexit Britain's immigration reception and integration policies have become progressively restrictive with strong neo-assimilationist and Eurosceptic overtones. This has angered Europeans in the UK, who have seen their status of "European citizens" reduced to that of "migrants" who have to apply for settled status to regain the right to remain in Britain.

Importantly, Bulgarian migrants have been discussed mainly in relation to the phenomenon of "Eastern European" migration to the UK. Semantically, the term "Eastern European migrant" 
is problematic as the literature reveals the negative connotations of the term, rigidly framed as a poor, uneducated, benefits-driven, potentially dangerous, unskilled migrant (Fox et al., 2012). Media representations of Bulgarians, like their Central and Eastern European counterparts, make no exception, establishing stereotypes which simplify migrants' motivations for relocation and experiences in Britain. Recently, Lulle et al.'s (2018) research has demonstrated that Brexit as a political "rupture" has strong affective connotations which accentuate the othering of EU migrants and also impact upon their migratory trajectories. This illustrates Pratsinakis' (2018) reminder of the importance of scrutinizing the ways in which nationalist discourses affect migrants' everyday lives and respectively identities, which is also the aim of this article.

\section{THEORETICAL FRAMEWORK}

Crossing borders in times of crisis produces anxieties in host and home societies alike. Migrants thus find themselves exposed to double-sided othering - a discursive realm where home and host discourses of othering stigmatize individuals and impact upon their identities (Author, 2017). Such processes entail "[...] differentiation and demarcation, by which the line is drawn between 'us' and 'them' - between the more powerful and the less powerful - and through which social distance is established and maintained" (Lister, 2004: 101). This clearly demonstrates not only that power, othering and identification are interlinked but also that their nexus is the result of a dynamic process of negotiation over the definition of the Self. Therefore, this section explores this process by looking at the nature and characteristics of identity and its nexus with othering. Ultimately, I argue that Tajfel and Turner's (1986) "social creativity" and "individual mobility" strategies provide a useful analytical lens of the ways in which national identity can be reinvented.

Importantly, this paper is premised on the understanding that migratory contexts illuminate and further stimulate the fluidity associated with the nature of identities. Bauman remarks that:

"Identity" is a name given to the escape sought from [...] uncertainty. Hence "identity", though ostensibly a noun, behaves like a verb, albeit a strange one to be sure: it appears only in the future tense. Though all too often hypostasized as an attribute of a material entity, identity has the ontological status of a project and a postulate (1996: 19). 
This provides an insight into the dynamism implied in "identity" as well as its complex nature. Therefore, "identity" emerges as a notion that is both ontologically ambivalent and epistemologically contested. Bauman's argument highlights the complex nature of "identity" as a point of fixture and meaning (or a "postulate"), and yet one which is constantly developing (as the reference to "project" suggests). This asserts that the elusiveness of the concept stems from identity building as an ongoing process, which needs to be embedded in its context. Therefore, understanding one's identities requires scrutiny of the essence of the process of constructing meaning itself.

Respectively, Hall's discursive approach is useful because it sees identification as a "process never completed", and "lodged in contingency" (1996: 2-3). The construction of a coherent self-narrative entails a process which is characterized by dynamism. As such, identification encapsulates the art of crafting the Self by drawing on a variety of elements which serve as sources of meaning. Hall's (1996) approach thus places emphasis upon "becoming" rather than "being". This outlines identification as an act of agency, accentuating its processual and situational features. Defining (Caribbean) cultural identities, Hall also asserts that they are "[n]ot an essence but a positioning" (italics in original, 1990:226). He further explains that such positionality is never unproblematic and straightforward; rather it is political, always framed by the vectors of similarity and continuity on the one hand, and difference and rupture on the other (Hall, 1990:226). Thus, clearly, identities are almost always interconnected with discourses of difference and othering.

Furthermore, Jensen (2011) maintains that identity formation embedded in discourses of difference or othering is not necessarily a passive categorization of people; it can also result in an expression of oppositional agency. Specifically, Jensen identifies two forms of agency which entail resistance: while capitalization appropriates elements of othering, refusal focuses on distancing from categorizations of difference (2011: 66). Although this understanding of the process of identification is useful in accentuating agency, it it does not account for cases when capitalization and refusal operate simultaneously. Therefore, I argue that the notion of reinvention allows a more thorough approach to identification, which incorporates the ability of the Self to react to crises by both capitalizing on them and refusing them. To illustrate this point further, the idea of reinvention is discussed below. 
"Reinvention" is deeply rooted in sociological observations which aim to understand the conditions underpinning the "fabric" of social relations in the $21^{\text {st }}$ century. Respectively, Bauman maintains that the core principle of postmodern life strategies is "recycling", rather than "creationas it was in modernity (1996: 18). He further emphasizes the primacy not of "identity building, but [of the] avoidance of fixation" (1996: 24). Thus, identification is conceptualised as a condition of restlessness and insecurity in fast-paced societies where flexibility and change lead to social progression, albeit not without emotional costs. Similarly, Elliott (2013) engages with the ways in which global processes transform societies across the world; however, he does so by lodging his argument in the idea of "reinvention". Specifically, Elliott argues that the times we live in, permeated by the forces of globalization, condone a lifestyle where "the art of reinvention is inextricably interwoven with the lure of the next frontier, the break through to the next boundary, especially boundaries of the self" (2013: 4-5). Therefore, restlessness is a condition that leads to progression, whereas stasis is perceived as decline. Elliott emphasizes the incessant need to renew and re-do which underpins life choices that celebrate the triumph of transformation over traditionalism. As he argues: "Reinvention is thus, in effect an experiment with possible versions of the self, an experiment with alternative versions of social life" (Elliott, 2013: 93). This definition, however, has both advantages and disadvantages. For example, Elliott's "reinvention" makes all-encompassing claims which risk oversimplifying complex phenomena. Yet, its value lies in its ability to capture the dynamic, fluid and multi-faceted nature of identities as they are embedded in their context. Therefore, I adopt a narrower understanding of reinvention, which emphasizes the dynamics of identification, embedded in their discursive context. This interpretation offers the possibility for an agency-led analysis of people's new routes of identification, which both capitalizes on and refutes negative discourses.

Ultimately, this paper argues that some young Bulgarians in Britain draw on the idea of the (new) Enlightener/Ambassador to make sense of and justify their migratory choices, redefining and reclaiming national identity in the process. To understand participants' identifications, I apply a social identity approach, which utilizes both social identity theory (Tajfel and Turner,1986) and its spin-off, self-categorization theory (Turner et al., 1987). Specifically, the latter recognizes that identity operates on different levels of inclusiveness: human identity (the self as superordinate category), social identity (the self as a member of a social in-group, which is defined against other groups of humans) and finally, personal identity, which is based on interpersonal comparisons 
(Turner et al. 1987). Focusing on social identity, I argue that for the participants, the in/out group differentiation in the home society context is based on a migratory choice, whereas in the host society context the division is along the lines of nationality (locals vs. migrants). Respectively, for migrant Bulgarians, fellow migrants become the "in-group", whereas home Bulgarians are the "out-group" when othering discourses in Bulgaria are considered. Additionally, drawing on Tajfel and Turner (1986), I argue that participants employ either "social creativity" approaches to social identity by seeking positive distinctiveness for the in-group, or "individual mobility" approaches which entail disassociation from the erstwhile group. Thus, while in the first case, participants seek to alter the evaluative connotations associated with the "Bulgarian/Eastern European migrant" to positively benefit the in-group, in the second case some seek to actively disassociate themselves from it. The individual engagement with stereotypes attributed to the social group unlocks a route of identification that enables the reinvention of national identity.

Importantly, the Enlightener/Ambassador is neither an ideal type, nor one that all Bulgarian migrants necessarily subscribe to. Instead, it is a reference point, which demonstrates the prevalence of certain characteristics of identification over others in particular moments. Additionally, it is evident that the Enlightener/ Ambassador idea has strong parallels with the literature on the migration-development nexus in terms of social remittances (Levitt 1998, 2001; Levitt and Lamba-Nieves 2011). Social remittances are these ideas, know-how, norms, values, practices and skills that migrants bring home with them or send home from abroad (Levitt 1998, 2001). Furthermore, as Levitt and Lamba-Nieves note, migrants' actions are rich in cultural meanings (2011:2), which also enables the examination of the frictions caused by the decision to migrate, or the stayers vs. leavers debate. Importantly, such discourses are incredibly gendered, with an increasing number of studies highlighting women's key contribution to social remittances or aiming to challenge gender-blindness and stereotypes (Kunz, 2008). Regardless, social remittances are at the centre of what my participants do or aim to do. However, this paper does not focus on the practice as such; its contribution lies at the investigation of how the idea of social remittances and migration in general impact upon young Bulgarians' (national) identities.

Thus, this paper explores the self-identification term of a (new) Enlightener as well as the rhetorical category of an Ambassador which are employed by the participants to negate Bulgarian and British othering discourses. These "routes of becoming" (Hall, 1996) and discursive 
constructions will be scrutinized by analysing the participants' everyday practices. Moreover, it will be argued that these notions signify an act of agency, which combines both capitalization and refusal of negative discourses. Next, however, the study's methodology is considered.

\section{METHODOLOGY}

The data presented in this article is part of a larger project on young, highly skilled Bulgarians in the UK, focusing on three focal points: what happens before, during and after migration. Firstly, the project explored the factors underpinning young Bulgarians' migratory projects and secondly, how they adjust to the host society and respond to othering. Thirdly, the project considered how the negotiation between migratory projects and realities impacts upon one's identities and plans for the future by asking participants to reflect on their experiences of migration and othering.

The main research instrument was semi-structured interviews as they seek "[...] to obtain descriptions of the interviewees' lived world with respect to interpretation of the meaning of the described phenomena" (Kvale and Brinkmann, 2009: 27). This technique allows the researcher "more latitude to probe beyond the answers and thus enter into a dialogue with the interviewee" (May, 2001: 123). Therefore, I was able to explore my participants' responses to othering discourses and their perceptions of self. I also had enough freedom to pursue specific themes such as the reinvention of national identity as it emerged from our "conversations with a purpose" (Burgess, 1984: 102). Most participants, despite being fluent in English, opted to be interviewed in Bulgarian and the quotes that appear in the text are my translations.

The interviews were supplemented by participant observation to further contextualize how young Bulgarians "practice" national identity in their everyday. Participant observation followed the natural course of events (Okely, 2012) and was not restricted to the location of interviews. I often found myself partaking in unexpected situations that yielded considerable research data: everyday situations, field trips and last-minute invitations to social gatherings. As the role of the researcher varies between participation and observation, informed consent was an ongoing process, usually verbally obtained in these situations. All names used are pseudonyms.

Bulgarian youth mobility to the UK is a rather elusive phenomenon to study due to the constant fluctuation of migratory flows. Nonetheless, statistical data clearly demonstrates an 
intensification of Bulgarian migratory flows, particularly of young and highly skilled people, since Bulgaria's 2007 accession to the EU (Maeva, 2010). To recruit participants, I used my "insider" status, employing two different techniques: judgement sampling and snowballing. While the first entails selecting participants based on "previous experience" and "special knowledge" and thus consisted of previous contacts; the second focuses on creating "chains of informants" (Burgess, 1984: 55). However, in both cases my sampling approach was purposive to counterbalance the lack of systematic statistical data. As such, the sampling approach focused on young Bulgarians aged between 18 and 35 with an equal split in terms of gender and occupation (both students and young professionals) to capture a wider spectrum of Bulgarian youth mobility. To account for any variation in terms of experiencing othering discourses in the host society, participants were recruited from various parts of the UK.

Fieldwork was carried out between August 2013 and November 2014, and 37 participants aged between 19 and 32 years took part. The gender split was 18 male and 19 female; 16 were young professionals and 21 were students. Respectively, as all participants were in approximately the same life stage (un-married, no children, early career), this meant that both men and women were equally active in employing either Enlightener or Ambassador routes of reclaiming national identities. Yet, gender differences could be discerned in the ways they did so, and these shall be briefly noted where relevant. Students were easier to recruit through student societies and they were more willing to participate as they had more free time in comparison to professionals. Twenty-six students either had already obtained or were studying for an undergraduate degree, seven were working towards a postgraduate taught degree and four towards a postgraduate research degree. Most participants came from large to middle-sized towns in Bulgaria but, crucially, they had all attended prestigious secondary schools with intensive English language training, which had fostered migration to Britain. Furthermore, the highest number of participants were all students who live in Scotland (12). This can be (partially) explained by the fact that the Student Awards Agency for Scotland covers their university tuition fees. The locations of other participants are as follows: the Midlands (10) and London (7), Northern England, (4), Southern England (2) and Wales (2).

The combination of qualitative research techniques employed in the research process helped to generate a rich data set. The data was analysed through a combination of thematic and 
narrative analyses where resistance and reinvention emerged as prominent themes, as will be demonstrated forthwith.

\section{THE (NEW) ENLIGHTENERS}

The idea of (new) Enlighteners centres upon studying or working abroad in order to eventually return to Bulgaria to implement those ideas, thus making a difference by "reviving" the nation. Thus, the (new) Enlightener as a form of self-identification is a reinvention of national identity by capitalizing on "old" Bulgarian historical narratives of migration to address the crisis in the country and refute the othering discourses it has produced. To understand the significance of this form of self-identification, this section first discusses the various conceptualizations of idea of the Enlightener. Next, by scrutinizing the participants' everyday practices, I analyse the characteristics of the new Enlighteners, simultaneously considering some of the criticisms.

The origin of the Enlightener dates to the late $18^{\text {th }}$ and early $19^{\text {th }}$ centuries when Bulgaria, having been under Ottoman rule for five centuries, underwent a cultural, educational and social renaissance which culminated in an organized revolutionary movement for liberation. The Ottoman Empire's expansion of trade with Europe enabled Bulgarian merchants to send their children to study abroad, mainly in Europe and Russia. While still abroad or upon returning, many of those foreign-educated (mostly male) young Bulgarians made a conscious effort to revive the feelings of nationalism among their fellow countrymen (Crampton, 2007: 50). Daskalov argues that these efforts can be roughly divided into three different, yet interrelated streams: education, a movement for an independent church (preceding armed actions), and revolutionary activity (2004: 151- 176). Therefore, the Bulgarian Revival remains an important period in Bulgarian history as it marked the country's transition to modernity by introducing the idea of Bulgarians as part of a nation. This in turn has embedded the image of the Enlightener in a strong mythical narrative, which has been successfully extrapolated and transmitted over the centuries, often romanticized in the process.

As the concept of the Enlightener has evolved over the years, it has been associated with political messianism. This was particularly evident in 2001 when many foreign-educated young Bulgarians returned to take key ministerial positions in the cabinet of the newly elected prime 
minister (and former Bulgarian king) Simeon Saxe-Coburg-Gotha. Furthermore, the return of foreign-educated Bulgarian men and women in the last few years has attained developmental connotations but more gendered nuance as they began taking up key positions in the growing third sector (BNT, 2016). Among the reasons for return such as patriotism and a strong sense of belonging (BNT, 2016), what emerges is the "mechanics" of reinvention and success conceptualized as "making a difference". Evidently, the idea of the Enlightener has various dimensions and a strong presence in the Bulgarian national discourse.

Correspondingly, it is thus unsurprising that some participants in Britain rely on this form of self-identification to justify their migratory choices. For example, . Boyan (age 23) works in a bank in Southern England but he spends most of his time theorizing what he defines as the "Second Bulgarian Revival" which mirrors its 18th-19th century equivalent. Therefore, Boyan is actively involved in many Bulgarian organizations - from student societies to professional groups and citizen initiatives. He also seeks different opportunities which allow him to expand his knowledge such as start-ups and trustee boards. Boyan also keeps a diary where he writes down ideas that he has come across, thinking about how they can be modified and implemented in Bulgaria. Thus, Boyan's everyday practices and his conceptualization of the (new) Enlighteners are an important route of identification that also serves to make sense of and justify his migratory decision. This process of identification entwines success with the home society, signifying that return, although distant, is a viable option. Furthermore, this "route of becoming" adopted by some of the participants places stronger emphasis on refuting Bulgarian stereotypes framing migrants as traitors and escapists. It does so by capitalizing on the "classical" understanding of a Bulgarian Enlightener. This approach characterizes migration not only as a justifiable but also a necessary choice. Psychology student Karolina remarks:

People like Levski, Botev and [...] Karavelov ${ }^{1}$ had received their education abroad prior to coming back to Bulgaria and making a difference. They managed to inspire people and contributed to the development of the Bulgarian nation as a people [...]. And I believe that many people, who study abroad [...] are here [Britain] because they want to go back afterwards and contribute to the development of our country. Therefore, I don't think that people who have come here are running away from the situation in Bulgaria.

The direct parallel between the Bulgarian Revival and current migratory outflows clearly establishes the idea of the Enlightener as a source of identification that helps Karolina make sense 
of a complex reality. Moreover, it frames migration almost as an act of patriotism, delineating the contours of an identification with caring characteristics, which diverts attention from the Self. Therefore, the reinvention of the Self is not the ultimate goal, it is simply a means to an end, that is, a contribution to the common good. Additionally, the idea of making a difference in the home society through social remittances, accentuates the presence of a very strong national identity. This directly corresponds to and rejects the Bulgarian stereotyping discourses in relation to migration. The various nuances of the new Enlightener as a process of identification also reveal the migrant narrative as a story of reinvention, driven by success. The latter, although conceptualized as improving the home country, ultimately entails a reinvention of the Self through a reinvention of the understanding of national identity. This confirms Karner's observation that national identity is "subject to ongoing negotiations involving competing visions of social order, alternative interpretations of history and delineations of national self' (2011:21). Thus, the (new) Enlightener is an everyday active rejection of Bulgarian stereotyping discourses, which frame migration as an act of treason. Such self-identification is significant as it encapsulates a strategy of "social creativity", aiming to present participants to fellow co-nationals back home as worthy and loyal.

While this type of identification affirms young Bulgarians' patriotism and moral values, it does not go uncriticized. Discussing the idea of the new Enlightener as an act of oppositional agency with marketing specialist Kalina, reveals that such a life path may be considered as unrealistic and naïve as it is "disconnected with Bulgarian reality". This is premised on the lack of opportunities for professional development in the country, which highlights the need of economic reform that needs to go alongside policy effort to attract foreign potential. Additionally, Kalina highlightsthe problematic assumption that the "stayers" are in need of "revival". Delyan, in the quote below, demonstrates an awareness of potential negative reception of the idea of the Second Bulgarian Revival:

When I came here in the beginning, my plan was to finish my education, to go home and to become prime minister by the time I am 40 . However, I realised afterwards that people see us - those of us who study abroad - they see us as outsiders that come from somewhere with the pretence to rule them. [...] It's almost as if those who have once left are not counted [as fellow citizens], it's as if they have already given up once. But it is not like that. Many people who have studied here are here precisely because they want to go back. 
This interview excerpt clearly demonstrates the external dimensions of identity, which pose a challenge to reinvention as an oppositional agency. It also highlights the tensions that social remittances can create between migrants and non-migrants (Levitt and Lamba-Nieves, 2011). Delyan's comment further demonstrates how "social creativity" operates by aiming to alter the evaluative attributes of the in-group of Bulgarian migrants when compared to the out-group of non-migrants (Tajfel and Turner, 1986: 20). Interestingly, however, making a difference here (Delyan's ambition to become a prime minister) has some markedly individualistic, gendered tenets, which question the extent to which success is perceived altruistically. However, the context

of the interview setting needs to be considered regarding self-identification: the participants were talking about countering stigmatizing discourses in Bulgaria with a fellow co-national who is also a highly skilled migrant. It is thus possible that the strong emphasis on national identity and belonging in interviews was yet another way of proving their loyalty. Nonetheless, participant observation demonstrates that framing success as making a difference in Bulgaria is an important element of the new Enlighteners as form of identification. The promise of return home upon completion of studies or the accumulation of "enough" experience is perceived as a factor counterbalancing othering. Thus, evidently, the participants reinvent the concept of national identity by both capitalizing on and refuting stereotypical representations of their migratory choices through the idea of the new Enlightener. The latter helps to motivate them to complete the migratory project, simultaneously highlighting the need for more consistent policy approaches that can transform return from a promise into a reality.

\section{AMBASSADORS}

The data shows that the participants not only see themselves as carriers of change in their home society but also as people who promote a more positive image of Bulgaria abroad. Thus, the idea of the Ambassador is closely linked to the new Enlightener. While both aim to refute stereotyping discourses, participants refer less explicitly to the idea of an Ambassador and, as such, this notion should be treated as a rhetorical category which entails mostly proactive strategies to counterbalance stereotypes forged in the British public space.

One of the most prominent characteristics of the Ambassadorial practice entails participants' effort to portray themselves positively in social situations. While many participants 
who demonstrate the new Enlightener or the related Ambassador characteristics are students, there are also some young professionals, such as Vasil. He explains his strong national identity thus:

When I find myself in a situation when they ask me where I am from, I always say that I am Bulgarian. For me this is a way to wipe away the shame associated with being Bulgarian. I do exactly the opposite. I am proud to be Bulgarian. I mean, it is not very pleasant that people associate Bulgarians with [something bad]. If you saw me in the street, you'd never tell that I was Bulgarian. But the moment I say I am Bulgarian, people's first association is negative [because of the negative media rhetoric]. However, if I demonstrate the opposite, they'd stop associating it with something bad.

This passage clearly signifies the discursive nature of young Bulgarians' national identities in everyday situations. The process of reinvention consists of highlighting one's nationality and focusing specifically on the positives, which serves to promote a better image of the entire migrant group. This signifies a "social creativity" strategy in Tajfel and Turner's (1986) terms. Vasil also displays many of the characteristics of the new Enlightener as he also actively tries to make a difference in Bulgaria, albeit from a distance. He does so by being actively involved in various initiatives that aim to attract highly skilled young Bulgarians to work in Bulgaria. Thus, he demonstrates that young professionals' identification routes are not clear-cut. While it is possible to indicate the precedence of certain forms of identification over others, the participants' narratives also highlight that identities are multiple, fluid and multidimensional.

Additionally, many participants take every opportunity possible to promote Bulgarian traditions to raise awareness about Bulgaria's rich cultural heritage, which serves as another manifestation of the Enlightener-as-Ambassador category. Kamelia's mission of "enlightenment" in relation to Baba Marta ${ }^{2}$ serves as a good example:

I do celebrate [national] holidays, yes, and I try to involve as many people as possible. When I am in the mood, I will celebrate the holiday properly. I have been doing these things since I was in primary school. So, for the 1st of March I will wear white and red. So, last year I went to a language café, which is part of the International Society. So, I went there wearing white jeans and a red jumper and had a bag full of martenitsi. ${ }^{3}$ I'd sit there and when I get talking to someone, I will say "By the way..." and I would tie a martenitsa on their wrist and tell them about the holiday. I tell everyone about the traditional holidays and explain to them where the tradition comes from.

Kamelia's celebration of Baba Marta is indeed reflective of how primary school students mark the day, which involves not only exchanging martenitsi but also wearing a matching outfit. Interestingly, this childhood memory has become a firmly established practice for her. Moreover, 
this practice not only affirms her identity, but it also allows her to spread awareness about her home country's culture and traditions. As such, a slight gender variation can be observed in how the Ambassadorial role is approached but men and women are equally active in employing it. In fact, with regards to Baba Marta, Bulgarian student societies in Glasgow, Aberdeen, Sheffield and Manchester collectively promote Bulgarian culture through organizing martenitsa workshops, later giving them out to other students on campus and explaining the traditions. In Sheffield, Nayden recounts that he recruited all his non-Bulgarian housemates to make martenitsi, which later the Bulgarian society sold for 50 pence each. The collected money they decided to donate to an orphanage in Bulgaria in order to "make a difference for the children".

The young Bulgarians who attach meaning and significance to Ambassadorial practices also use everyday situations to express their oppositional agency to British stereotypes. Everyday conversations may establish a firm us-them line of division, leaving many participants feeling as the Other. The latter becomes evident in everyday talk about popular shows, activities and food which are very typical for young people growing up in Britain. While for many of the participants this reaffirms their otherness, Vasil's strategy to manage such situations turns them into an opportunity to tell his friends more about Bulgaria:

I usually tell them [British friends] that Bansko is great for skiing. I usually talk about the difference in weather conditions because a conversation about the weather is the easiest you can start here. I always use it as an opportunity to turn around and say: 'Well, it is not the same in Bulgaria. The temperature varies from minus 10 to plus 40, so the day can start with 10 degrees and end in 30". But yes, these are the type of things I share with people - everyday things, not [historical] facts.

Thus, sharing information about everyday peculiarities associated with Bulgaria allows the participants to dispel myths about the country and its nationals. This example shows that the reinvention of national identity through the idea of the Ambassador embraces points of difference, simultaneously transforming othering into opportunities to engage in "social creativity". Evidently, the Enlightener/Ambassador mode ultimately helps some of the participants to make sense of their complex realities and justify their migratory choices. Making a difference is, therefore, seen as success, conceptualized in terms of altruistically contributing to the common good - either by promoting a positive image of the home country or by gathering experience to be implemented upon return. 
Yet, once again, referring to the idea of an Ambassador of Bulgaria as a way of navigating the hostile host environment has its critics. Investment banker Paula, for example, is adamant that her success and achievements have nothing to do with promoting a better image of Bulgaria. "At the end of the day, it is about my development and my career" (my emphasis), Paula says. This statement clearly demonstrates the shift from "social creativity" to "individual mobility" strategies. This becomes more evident when we consider Kalina's comments that she is different to "someone who has come here to have a better life but a bit lower class in general. Someone who works at Tesco's”. Kalina's comment not only makes a reference to her highly skilled status but also suggests that she tries to disassociate herself from fellow co-nationals in the UK who are considered as low skilled. This links to the overall negative image of a Bulgarian/Eastern European migrant and it also demonstrates the importance of class, particularly in terms of shaping nativemigrant relations and determining belonging to the nation. In this context, Pratsinakis remarks that more affluent and highly educated migrants "are more powerful in countering the accusations expressed by native citizens" (2018: 15). Therefore, young Bulgarians' highly skilled status may indeed be what enables them to engage in "social creativity" strategies, or even to choose "individual mobility" in situations that question their migratory choices, belonging and identity. Regardless, the meaning and significance attached to idea of the Ambassador are very much the product of the crises the UK is currently undergoing, which portray Bulgarians and other Central and Eastern Europeans as unwanted Others.

\section{CONCLUSION}

The multiple and ongoing crises in Europe and their intersection on both supranational and national levels have affected people's migratory stories, questioning the principle of freedom of movement. Thus, this article focused on the ways in which young Bulgarians manage crises through their everyday practices and how that impacts upon their sense of national identity.

The uniqueness of post-accession Bulgarian youth mobility is embedded in a context where the crisis narrative and migration intersect prominently the concerns of British and Bulgarian policymakers alike. As demonstrated, in Bulgaria the arguably never-ending process of transition and its socio-economic and political implications have conceptualized migration as a coping 
strategy. This has not only created a rupture between "stayers" and "leavers", but it has also framed migratory choices as an act of treason or escapism. Similarly, in Britain, the recent vote to leave the EU has highlighted the strong tendencies of Euroscepticism and neo-assimilationism as well as frustrations and dissatisfactions associated with the socio-economic situation in the country. These anxieties have been projected on to the intensifying migratory flows of Central and Eastern Europeans, raising questions about access to resources.

Correspondingly, the paper has demonstrated that Bulgarian students and young professionals enact oppositional agency by drawing on the idea of the (new) Enlightener or Ambassador to counterbalance negative discourses in home and host societies alike. Premised on its $18^{\text {th }}$ century counterpart, the (new) Enlightener justifies migration as a necessary step which can better the home society. It does so by associating migration with social remittances that could benefit development in Bulgaria. This aspect directly addresses the crises in Bulgaria and their negative discourses. Similarly, the Ambassador entails proactive strategies that involve personal success which can then serve to improve the image of the whole migrant group. It also entails dispelling myths and negative perceptions about Bulgaria and its nationals by "enlightening” British citizens about Bulgaria's rich culture and traditions. Respectively, the idea of the (new) Enlightener as selfidentification and the Ambassador as a rhetorical category demonstrate the fluidity of identities, their susceptibility to context and how social remittances can serve as a way of reclaiming national identity.

Nonetheless, the premises of identifying as a (new) Enlightener or using the "Ambassador" term are problematic. Their altruistic tenets are based on a possible but not confirmed return to a country that does not necessarily offer socio-economic stability and opportunities for development, according to some participants. Furthermore, these reinvented national identities assume that migratory experiences offer superior education and professional expertise than those gained in the home society. Additionally, such routes of identification not only presume that "stayers" need or want to be "enlightened" but, on a larger scale, they reaffirm stereotypical perceptions of "Eastern Europe" or Bulgaria as "backward". As such, the idea of the (new) Enlightener, instead of diminishing, can further accentuate the rift between "stayers" and "leavers".

Furthermore, the (new) Enlightener/Ambassador ideas not only transform home Bulgarians into an out-group but also unlock a process of reinvention of national identity, which both refutes 
and embraces to an extent stereotyping discourses in Bulgaria and Britain. This is demonstrated through the interplay between "social creativity" and "individual mobility" strategies (Tajfel and Turner, 1986) that the participants employ either to achieve a positive image of the entire group or to dissociate themselves from fellow co-nationals. Respectively, young Bulgarians' affluent status needs to be considered in the symbolic power struggle over belonging. Enlightener/Ambassador practices remain gendered albeit both males and females are equally active in employing them. Additionally, the rise of nationalism in light of the crises in both countries and the stereotypes that they have produced in relation to migration are not necessarily counterbalanced with cosmopolitan ideas. Instead, rejection and opposition in the everyday are firmly embedded in those same discourses. This shows that although young Bulgarians lead transnational lives, the extent to which the current climate of crises can lead to de-nationalized migratory projects (Favell, 2008) is questionable. Indeed, national discourses have not only retained but also further accentuated their salience, affecting migrants' everyday realities (Pratsinakis, 2018).

Thus, this paper's contribution lies in providing an insight into the difficulty of balancing loyalties in home societies, while also attempting to live up to the expectations of host societies. The article further demonstrates how migrant everyday practices and social remittances impact upon their national identities, this offering useful insights for policymakers. Respectively, based on this research several recommendations could be made. Firstly, in Bulgaria efforts to attract foreign-educated Bulgarians should go alongside more consistent measures to improve the educational system and economic situation in the country. This will not only improve the chances for return of young, highly skilled Bulgarians, but it will also bridge the rift between "stayers" and "leavers". The tension between the latter two requires more attention and drive to offer alternative, cosmopolitan discourses that counter the perception of migration as escapism. Thus, a governmental "Ambassadorial" policy approach to freedom of movement and better use of European information centres could go a long way into bridging gaps. Secondly, in Britain policymakers should only cautiously refer to all migrants born east of Germany and Austria as “Eastern European”. Post-Brexit legislation should not only guarantee European migrants' rights as workers and students but also consider offering incentives and encouragement for migrants to remain in the UK in order to retain and benefit from their skills and qualifications. The latter places key emphasis on how plans for the future immigration system are presented to the public. 


\section{NOTES}

${ }^{1}$ Bulgarian revolutionaries during the Revival period. See Crampton (2007).

${ }^{2}$ National Holiday celebrated on the $1^{\text {st }}$ of March when Bulgarians exchange bracelets made of white and red thread for good luck, health and happiness.

${ }^{3}$ Small red and white wrist-bands or adornments exchanged on the $1^{\text {st }}$ of March.

Bauman, Z.

1996 "From pilgrim to tourist or a short history of identity". In Hall, S. and P. du Gay (eds.) Questions of Cultural Identity. (pp. 18- 36). London: Sage Publications.

BNT

2016 Do Evropa I Nazad. Kakvo shte Varne Mladite U Doma. [Tv programme] Accessed: January 3, 2019. Available from: https://www.bnt.bg/bg/a/do-evropa-inazad-kakvo-shte-varne-mladite-balgari-u-doma.

Bozhidarov, D.

2012

Mladite vizhdat samo dva izhoda ot krizata v Bulgaria- Terminal 1 I Terminal 2, [Webcafe Online]. Accessed: September 10, 2017. Available from: http://www.webcafe.bg/webcafe/obshtestvo/id_1342784288.

Burgess, R. G.

1984 In the Field: An Introduction to Field Research. London: Allen \& Unwin.

Crampton, R. J.

2007

Bulgaria. Oxford: Oxford University Press.

Daskalov, R.

2004

The Making of a Nation in the Balkans: Historiography of the Bulgarian Revival. Budapest: CEU Press.

Elliot, A.

2013 Reinvention. London: Routledge.

Favell, A.

$2008 \quad$ Eurostars and Eurocities: Free Movement and Mobility in an Integrating Europe. Oxford: Blackwell Publishing.

Fox, J. E., Moroșanu, L. and Szilassy, E.

2012 "The racialization of the new European migration to the UK, Sociology, 46 (4), pp. 680-695. 
Glick Schiller, N., Basch, L. and Szanton Blanc, C.

1995 "From immigrant to transmigrant: theorizing transnational migration", Anthropological Quarterly, 68 (1), pp. 48-63.

Hall, S.

1990

1996 "Introduction: Who needs identity?". In S. Hall and P. du Gay (eds.) Questions of Cultural Identity (pp. 1-17). London: Sage Publications.

Jensen, S. Q.

2011 "Othering, identity formation and agency", Qualitative Studies, 2 (2), 63-78.

Kalinova, E. and Baeva, I.

2011 Balgarskite Prehodi: 1939-2010. Sofia: Paradigma.

Karner, C.

2011 Negotiating National Identities: Between Globalization, the Past and 'the Other'. Farnham: Ashgate.

Krasteva, A.

2014

Ot Migratsia Kam Mobilnost: Politiki I Patishta. Sofia: Izdatelstvo na Nov Balgarski Universitet.

Kunz, R.

2008

"Remittances are Beautiful'? Gender Implications of the New Global Remittances trend". Third World Quarterly, 29(7): 1389-1409.

Kvale, S and Brinkmann, S.

2009 Interviews: Learning the Craft of Qualitative Research Interviewing. (2 $\left.{ }^{\text {nd }} \mathrm{ed}\right)$. London: Sage Publications.

Levitt, P.

1998 "Social Remittances: Migration Driven Local-Level Forms of Cultural Diffusion". International Migration Review, 32(4), 926-948.

2001 The Transnational Villagers. Berkeley and Los Angeles: University of California Press.

Levitt, P. and Glick Schiller, N.

2004 "Conceptualizing simultaneity: a transnational social field perspective on society", International Migration Review, 38 (3), 595-629.

Levitt, P. and Lamba-Nieves, D.

2011 "Social Remittances Revisited". Journal of Ethnic and Migration Studies, 37(1): 122.

Lister, R. 
Lulle, A., Moroșanu, L. and King, R.

2018 "And then came Brexit: experiences and future plans of young EU migrants in the London region", Population, Space and Place, 24 (1), 1-11.

Maeva, M.

2010

"Organizations and institutions of Bulgarian emigration in the UK', in Karamihova, M. (ed.). European Dimensions of Culture and History on the Balkans. (pp.276291). Sofia: Paradigma.

May, T.

2001

Social Research: Issues, Methods and Process. ( ${ }^{\text {rd }}$ ed.). Maidenhead: Open University Press.

Okely, J.

2012

Anthropological Practice: Fieldwork and the Ethnographic Method. London: Berg.

Pratsinakis, $\mathrm{M}$.

2018

"Established and outsider nationals: immigrant-native relations and the everyday politics of national belonging", Ethnicities, 18(1): 3-22.

Sierp, A. and Karner, C. (eds.)

2019 Dividing United Europe: From Crisis to Fragmentation? London: Routledge.

Tajfel, H. and Turner, J. C.

1986 "The social identity theory of intergroup behaviour", Psychology of Intergroup Relations, 5, pp.7-24.

Turner, J. C. et al.

1987 Rediscovering the Social Group: A Self-Categorization Theory. New York: Blackwell. 